\title{
Pit wall optimisation and effective wall management strategies at Invincible Open Pit, St Ives Gold Mines
}

\author{
M Abdulai Gold Fields Australia Pty Ltd, Australia \\ PG Andrews Gold Fields Australia Pty Ltd, Australia \\ D McMahon Gold Fields Australia Pty Ltd, Australia \\ E Bona Gold Fields Australia Pty Ltd, Australia \\ J Walker Gold Fields Australia Pty Ltd, Australia
}

\begin{abstract}
The requirements for open pit wall optimisation are often reliant on the drive for maximum ore extraction while maintaining the stability of the individual benches and overall slopes. In a very basic sense, slope optimisation can mean increasing the slope angles and/or bench heights and deepening of the pit against the original design with an objective to integrate the allowable factor of safety into the mine planning. This exercise comes along with the implementation of effective wall management practices such as attaining operable berm catch capacity, drill and blast design practices and procedures that address poor batter condition. The optimisation of pit slopes to achieve a steep deep pit and still maintain slope stability is often seen as challenging without the integration of batter steepening trials within selected geotechnical domains to understand if the rock mass can support the steep slope strategies.

The Invincible Open Pit is known for fair to good quality rocks and high porewater pressures. It was decided to change the slope configuration by adopting $20 \mathrm{~m}$ batters instead of $15 \mathrm{~m}$, and to deepen the pit according to the experience gained with the slope from interim 'staged' pit walls. However, conducting drilling and blasting and wall excavation without having negative impact on the pit walls is a major geotechnical challenge. The paper will detail how the geotechnical team addressed this challenge and will demonstrate the improvement in the drilling, blasting and excavation of the walls leading to improved results in terms of safety and design reliability.
\end{abstract}

Keywords: pit slope optimisation, drill and blast

\section{Introduction}

St Ives Gold Mine is owned by Gold Fields Australia Pty Ltd, and it is located within Lake Lefroy, approximately $6.5 \mathrm{~km}$ south of Kambalda and about $75 \mathrm{~km}$ southeast of Kalgoorlie, as well as approximately $650 \mathrm{~km}$ northeast of Perth, in Western Australia.

In 2012 the Invincible deposit was discovered and in 2013 a feasibility study was undertaken that led to the establishment of the Invincible Open Pit in late 2014. An aerial view of the pit is provided in Figure 1 . The pit includes six staged pits with a strike length of around 1,925 $\mathrm{m}$ and width of $800 \mathrm{~m}$. The maximum depth of the pit is $165 \mathrm{~m}$-Stage 5 pit. St Ives is currently producing from the Stage 6 pit after producing approximately $786,425 \mathrm{koz}$ of gold from Stages 1, 2, 3, 4 and 5 pits.

The geotechnical study for the Invincible pit was carried out in-house in September 2013 and peer reviewed by Itasca Pty Ltd in June 2014 to assess the stability of the proposed slopes with regards to medium to large-scale batter stability. In the fresh rock it is was identified that any pit wall failures would likely be structurally controlled to some extent. It was recommended that additional analyses be carried out during mining as other medium and large-scale structures are identified. 


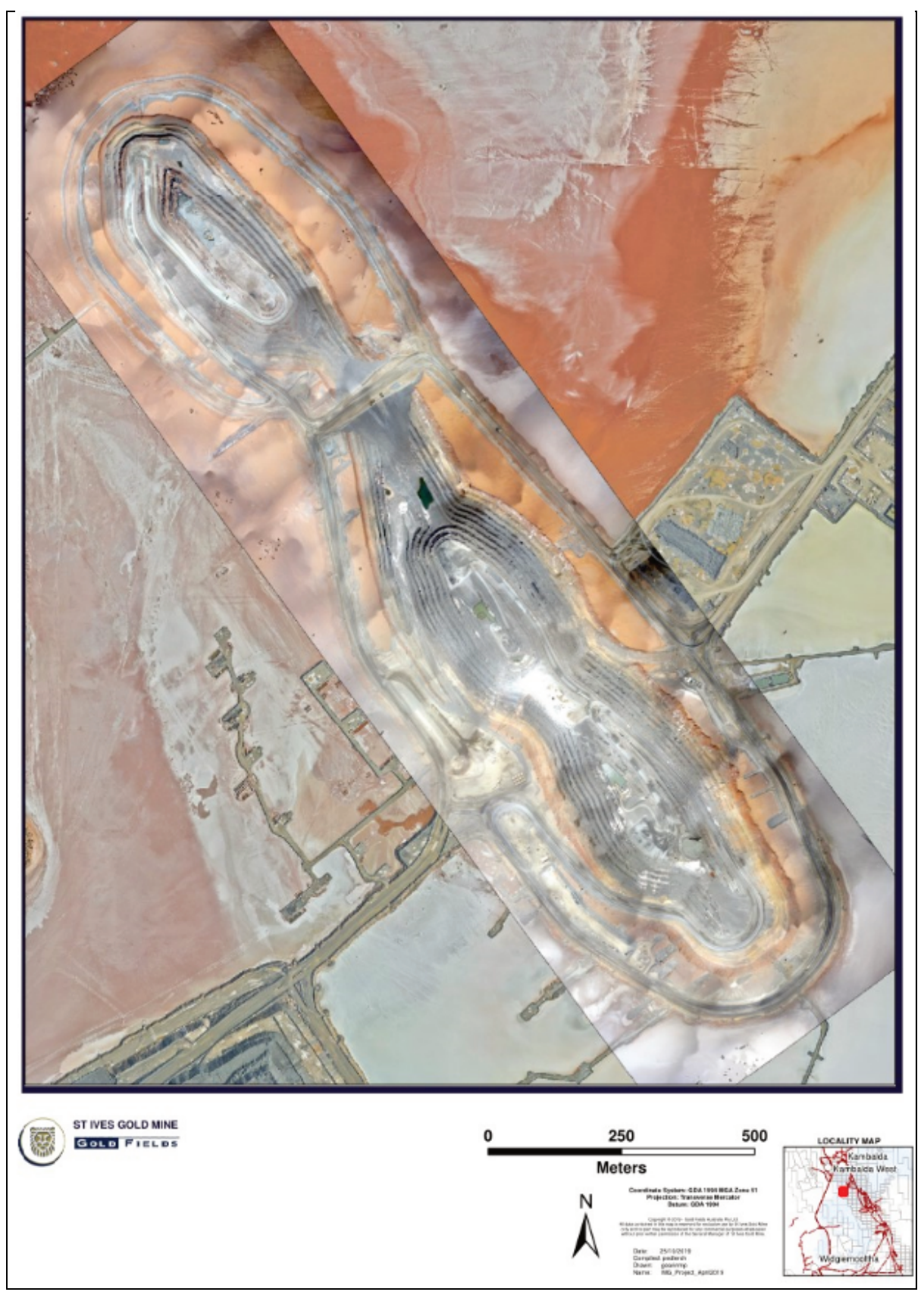

Figure 1 Aerial image of Invincible pit (pit flown on the 14/10/2019)

\section{$2 \quad$ Engineering geological settings}

The Invincible geology is mainly sedimentary rock and it comprises four main rock units:

- The Merougil Creek Beds (MER) which consist of quartz wacke, sandstone, and polymictic conglomerate. The majority of the west wall in the final pit is situated in these materials.

- The Black Flags Mudstone (BFM) which is the main ore-bearing rock. The bedding or foliation in this unit strikes northwest and dips steeply $\left(70^{\circ}\right)$ to the southwest. The lower three to four benches of the final walls in both east and west walls are situated in this unit.

- The Black Flags Andesite (BFA) which consists of sandstone/quartz-wacke, polymictic conglomerate, and volcanoclastic breccia. These materials make up the majority of the east wall in the final pit. 
- There are two unmineralised mafic, east-west trending and nearly vertical Proterozoic (dolerite) dykes of approximately $40 \mathrm{~m}$ width that intrude the sedimentary rocks at the north and south ends of the orebody.

A plan showing the geological setting in the Invincible area is provided in Figure 2. An oblique view showing the location of the mudstone and dykes in relation to the pit shell is shown in Figure 3.

A large-scale fault known as the Alpha Island fault (AIF) exists at the southeast corner of the pit. The AIF is near-vertical and strikes approximately north-south and is not undercut by the slope (Figure 4). The oxide and transitional slopes partially exposed the margins of the AIF.

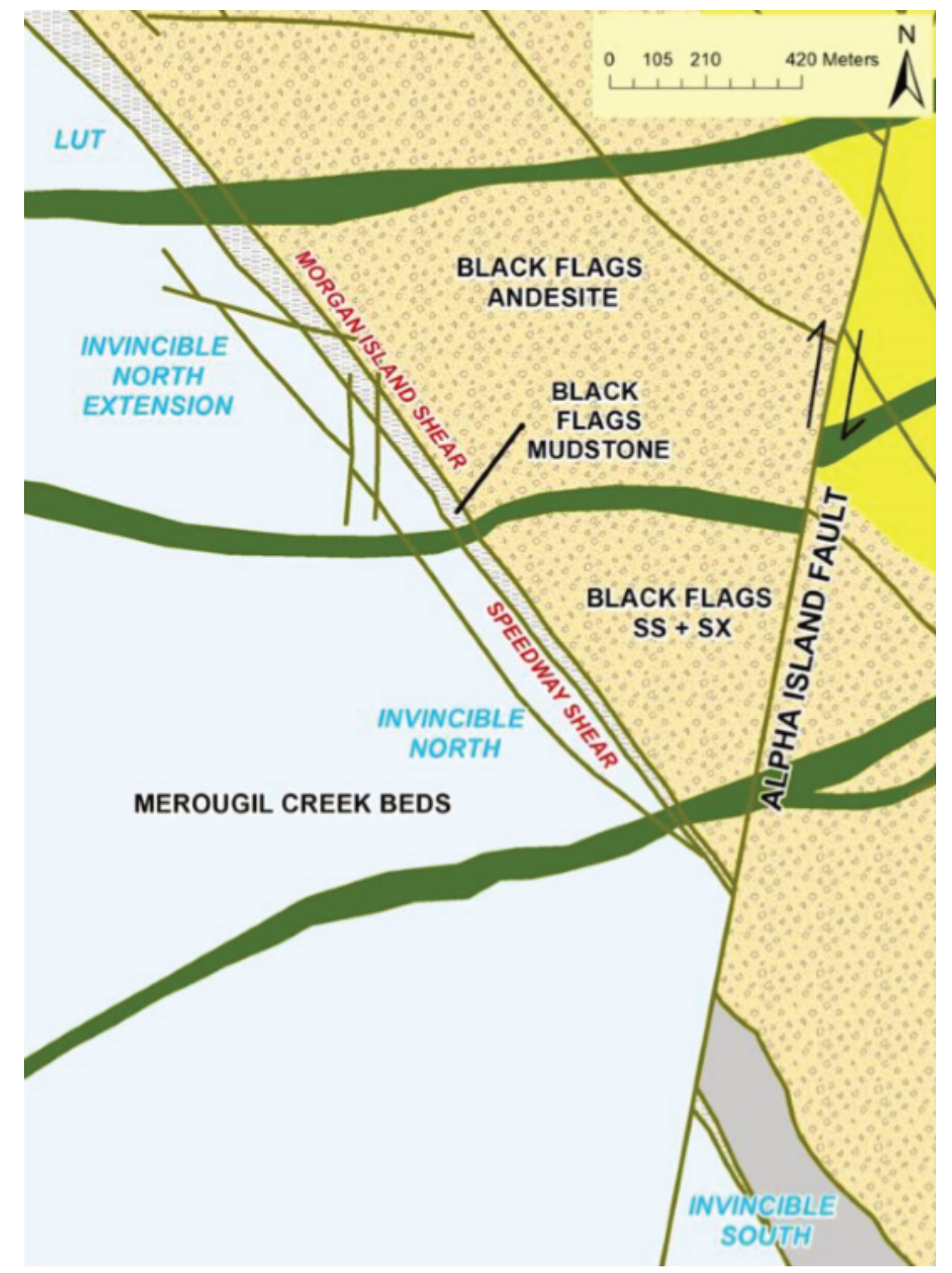

Figure 2 Geological setting in the Invincible pit area 


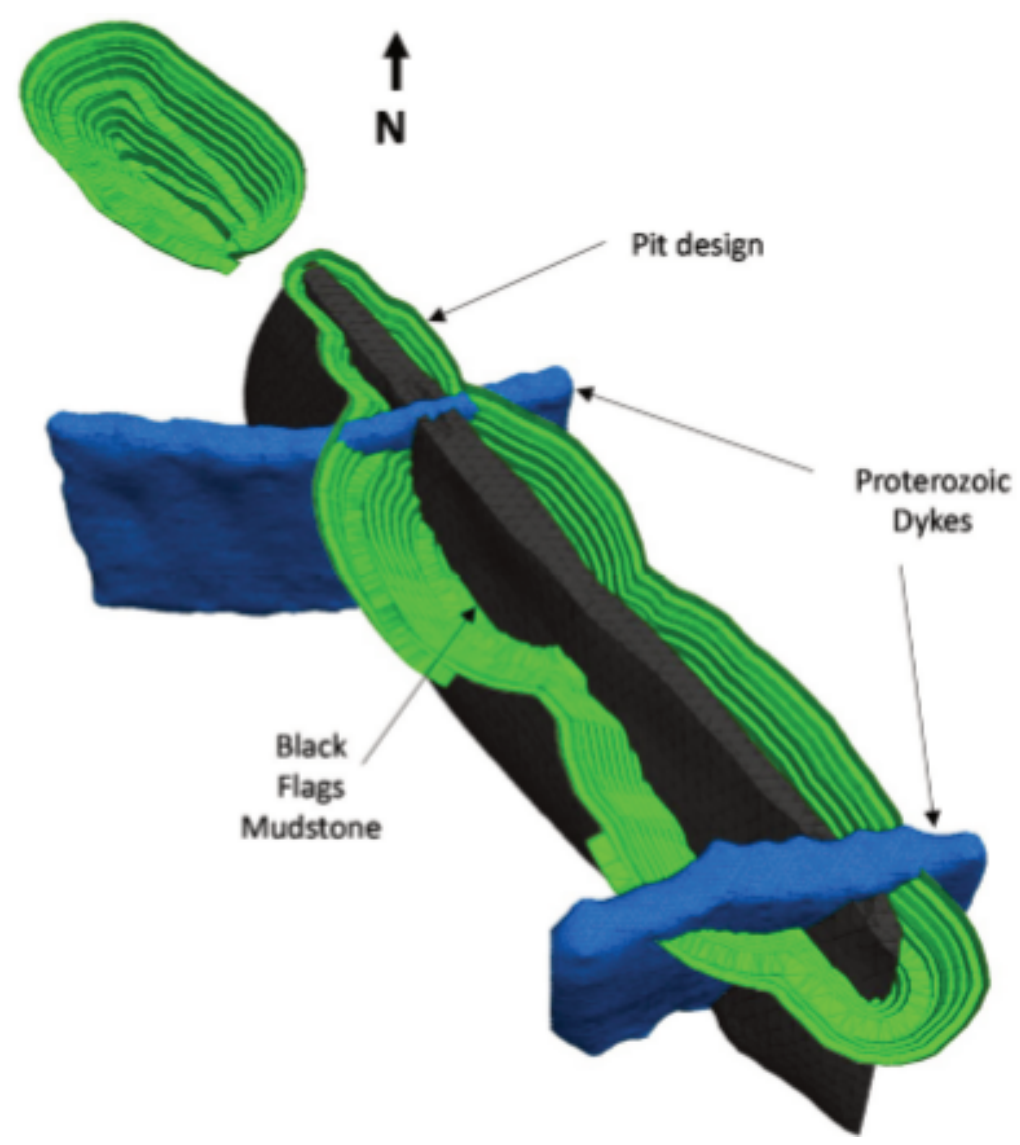

Figure 3 Pit design showing the geological features (Itasca Pty Ltd 2014)

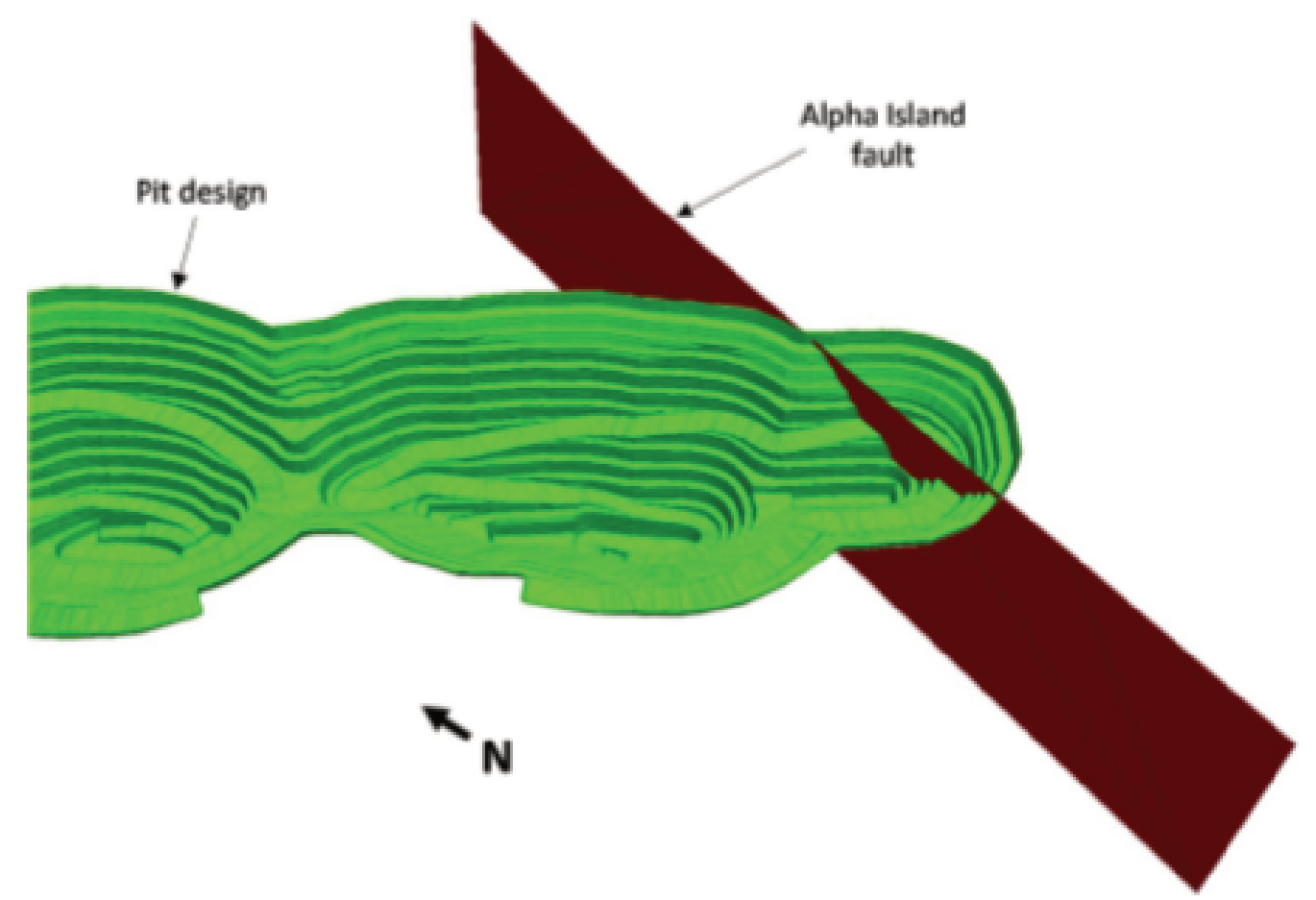

Figure 4 View showing the location of the Alpha Island fault in relation to the pit design (Itasca Pty Ltd 2014) 
Two large shears namely the Morgan Island Shear and Speedway Shear transect the entire Invincible pit from the northwest to the southeast. The shears appear to dip towards the southwest at approximately $65^{\circ}$. The Speedway Shear is found in the upper surface of the BFM whereas the Morgan Island Shear is contained within the BFA at similar dip angle to the Speedway depths.

The rock units at Invincible have been weathered to depths of up to approximately $55 \mathrm{~m}$ below the ground surface. The weathering comprises lake sediments of approximately $15 \mathrm{~m}$ thickness, underlain by saprolites with thickness between 15 and $20 \mathrm{~m}$; the depth of transitional material or saprock underlying the above sequence is around $15-20 \mathrm{~m}$.

Invincible has connecting tributaries to the east and south of the pit. The main hydrogeological units identified within the Invincible area are lake sediments, a permeable unit related to fracturing in the upper portion of the fresh rock within BFM, and an impermeable unit characterised by clay lenses in the lake sediments and saprolitic weathered profile. Again, intense fracturing along bedding and fractured rock potentially enhances permeability as observed in most parts of the west wall of the pit.

\section{Rock mass characterisations}

The east and west walls of the Invincible pit are largely developed in sandstone intruded by dolerite dykes. The uniaxial compressive strength (UCS) of the fresh BFA sandstone rocks is between 125 and $165 \mathrm{MPa}$ and rock mass rating (RMR) ranges from 60 to 80 , whilst the MER sandstone has UCS from 140 to $150 \mathrm{MPa}$ and RMR value ranging between 56 and 77. The BFM, which is centrally located and runs parallel to the pit along strike, is defined as fair to good rock having RMR of 43-76 and average UCS of 100 MPa. The dolerite dyke is friable when exposed and includes orthogonal joint sets resulting in blocky rock mass with RMR of 48-61; the average UCS of the dolerite dyke is $195 \mathrm{MPa}$.

The average bedding orientation of the BFA unit is $75^{\circ}$ with dip direction between 220 and $245^{\circ}$ and the structural orientations of the BFA are consistent with the MER. The maximum dip of bedding facing west $80^{\circ}$. The BFM has orientation of $65^{\circ} / 235^{\circ}$; within the BFM unit there is bedding shear and its dip angle varies between 60 and $70^{\circ}$ dipping to the west. There are three main discontinuities plus random sets on both the east and west walls (Figure 5). At depth within the MER the bedding varies from being non-existent to fairly developed. Within BFA and MER the rock mass is characterised by several sets of joints dipping at $\sim 32^{\circ}$ to $83^{\circ}$ and that have a wide range of orientations. The relatively flat lying joints are prevalent in the top two benches of the fresh sandstone across the pit walls and have resulted in some berm crest damage during blasting.

The discontinuity surface of the bedding planes in the BFA and BFM units are generally smooth planar to smooth undulating, and the joint structures are rough undulating. The Morgan Island Shear is not adversely oriented with respect to slope stability compared to the Speedway Shear within the MER but randomly undercuts the west wall with potential for toppling style of surface failure. This shear has not resulted in multiple bench and overall slope instabilities; however, the discovery of these structures has caused geotechnical engineers to remain vigilant when they are intersected as there is potential risk associated with large rockfalls, bench scale instability and ramp instability. 

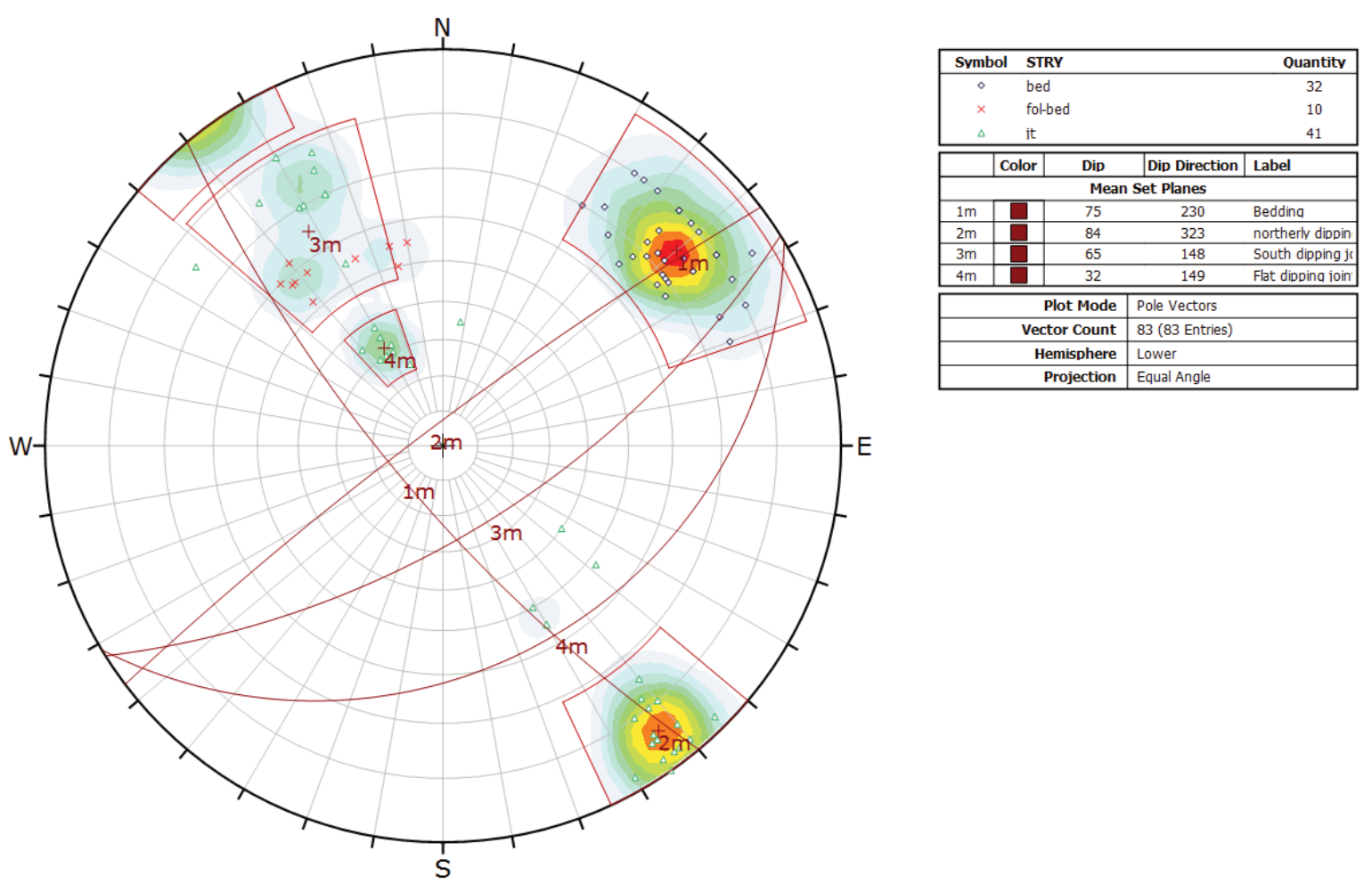

Figure 5 Stereographic plot from window mapping

\section{$4 \quad$ Pit slope design and configurations}

The slope configuration across the pit by material type is summarised in Table 1 . The lake sediment slope was mined at $70^{\circ}$ at bench height of $10 \mathrm{~m}$ and $10 \mathrm{~m}$ berm width, whilst the oxide and transitional slopes were mined between $55^{\circ}$ and $65^{\circ}$ at bench height $10 \mathrm{~m}$ and berm width of $6-7.5 \mathrm{~m}$. Originally the slope geometry design for the fresh rock across the entire pit walls was $75^{\circ}$ bench face angle at $15 \mathrm{~m}$ bench height and a berm width of $7 \mathrm{~m}$; this configuration was applied to the first two benches in the fresh rock slopes across the pit. No geotechnical berm was incorporated or recommended in the design of Invincible slopes.

Table 1 Slope configuration scenarios (Bruggeman 2014)

\begin{tabular}{lllll}
\hline Material type & $\begin{array}{l}\text { Batter angle } \\
\mathbf{(}^{\circ} \mathbf{)}\end{array}$ & $\begin{array}{l}\text { Batter height } \\
(\mathbf{m})\end{array}$ & $\begin{array}{l}\text { Berm width } \\
(\mathbf{m})\end{array}$ & $\begin{array}{l}\text { Inter-ramp angle } \\
\left.\mathbf{(}^{\circ}\right)\end{array}$ \\
\hline Lake sediments & 70 & 10 & 10 & 36 \\
Oxide/transition & 55 & 10 & 5 & 40 \\
\#1 Fresh rock & 70 & 10 & 5 & 49 \\
\#2 Fresh rock & 75 & 15 & 7 & 53.7 \\
\#3 Fresh rock & 75 & 20 & 7 & 58.2 \\
\hline
\end{tabular}

From the in-house slope stability analyses carried out using Slide2 (in terms of Factor of Safety (FS) and probability of failure (PF)), the FS values obtained were greater than 1.5 which meant the slope configuration could be altered. The acceptable criterions for stability of the walls in accordance with St Ives Gold Mine pit wall performances have chosen as follows: bench scale (FS $>1.1$ and PF $<35 \%)$, inter-ramp scale (FS $>1.2$ and $\mathrm{PF}<10 \%$ ) and overall scale (FS $>1.3$ and $\mathrm{PF} \leq 5 \%)$. The configurations produced probability of failure of $<2 \%$. The results including the stability methodology were provided to Itasca Pty Ltd (2014) for external review. Three sections were selected by Itasca for numerical modelling in conjunction with resident geotechnical engineer (Figure 6). For all sections analysed by Itasca Pty Ltd (2014) using UDEC, no slope failures are 
predicted by the stability models after excavation of the proposed pit. The results of the analyses showed the following:

- No overall slope failure occurred in the models when the strength properties were reduced by a factor of 2.0. Therefore, in terms of overall (global) stability, the safety factor for all three cross-sections modelled was at least 2.0.

- When the strength properties are reduced by a factor of 1.5 , no failures occurred in the models. Therefore, in terms of inter-ramp stability, the safety factor achieved for all three sections was at least 1.5.

- Failure occurred in the weathered materials when the strength properties are reduced by a factor of 2.0. Therefore, in terms of inter-ramp stability, the safety factor for this material is between 1.5 and 2.0.

- The AIF affected the modelled displacements but did not cause slope failure in the model.

The results obtained created the possibility for further change in slope configuration, with the potential to increase the batter height to $20 \mathrm{~m}$ (Table 1).

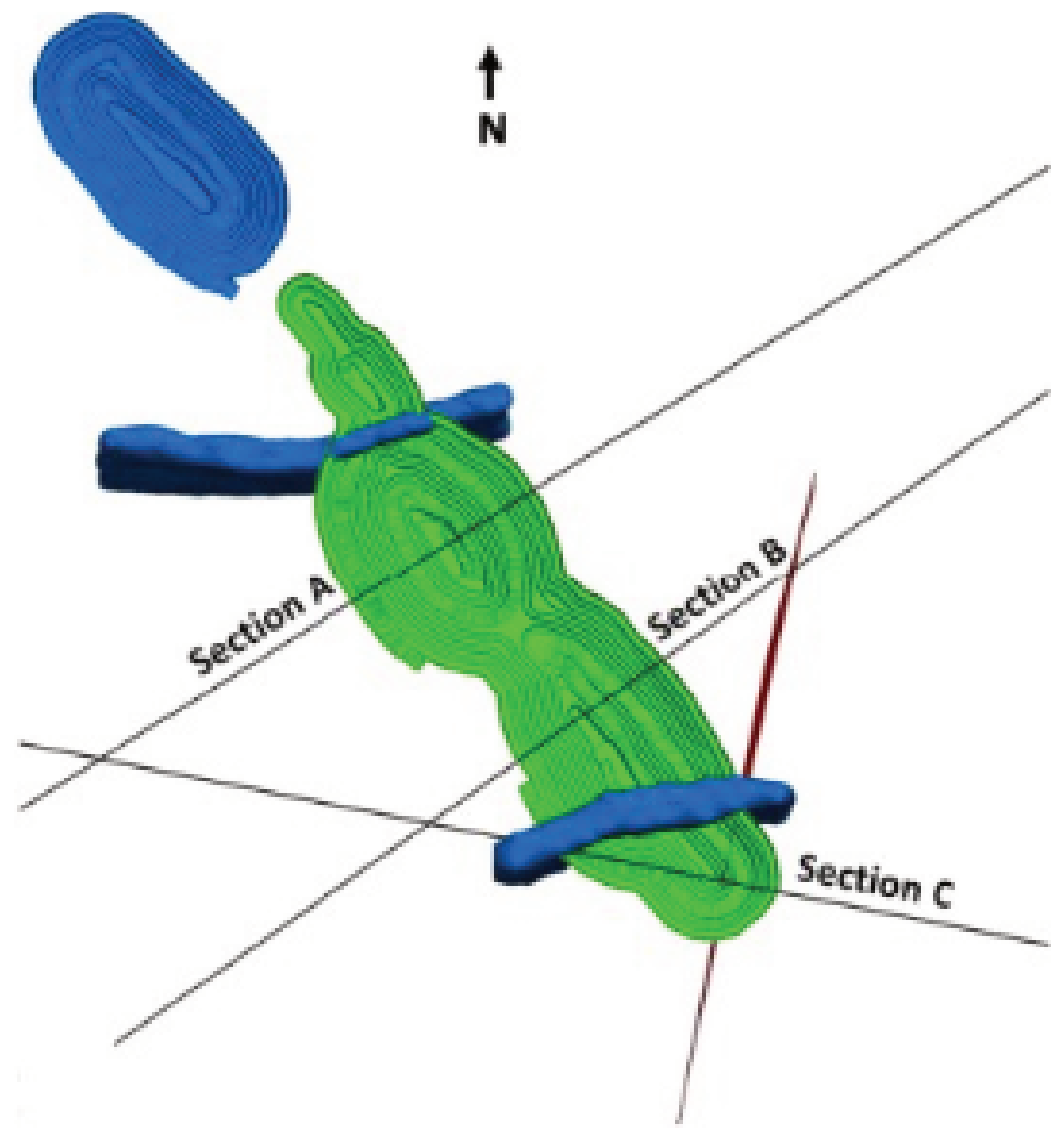

Figure 6 Plan view showing three analysis sections in relation to the pit design (Itasca Pty Ltd 2014)

\section{$5 \quad$ Pit slope optimisations}

The aim of the pit slope optimisation exercise was to determine if greater batter height and batter angle could be tolerated. Hence additional slope stability re-runs were completed based on modified failure criteria (using the defined parameters and the derived upper end parameters in Roclab) within the overall slopes, and in addition statistical interrogation was applied to try and determine if any significant variation from expected results was to be achieved. It therefore became prudent to trial $20 \mathrm{~m}$ bench heights at $75-80^{\circ}$ 
batter angles within interim walls. This way, the trialled wall configuration could be monitored for signs of instability, and of course operational ability.

To meet the requirement for item '\#3 Fresh rock' in Table 1, a geotechnical mapping campaign was launched during the mining of Stage 1 and 2 pits. The focus of the mapping exercise was to access the possibility of adopting steep slopes in localised domain areas and/or between certain levels of the slope domain with $75^{\circ}$ batters and $7 \mathrm{~m}$ berms.

The following geotechnical exercise was undertaken:

- Geotechnical Blockiness Index (GBI) (Walker \& de Bruyn 2006), window mapping and photogrammetry to characterise rock structures and determine rock mass fabric.

- Comparison of pit design and as-built slopes, to measure the effect of design across structural domains in the different rock mass units, and the impact of varying wall control blasting involving presplit, trim blast and occasionally 'stab holes' (including effectiveness of berm crest, damage to berm crest and wall scaling practices).

- Slope displacement monitoring using prisms (in the weathered slopes), photography and visual observation to understand the long-term slope response to blasting and rainfall events.

- Recording of rockfalls and slope failures event to understand the sources and triggering events.

- Two-dimensional finite element analysis of fully developed benches to understand the expected deformational behaviour under the different batter configurations.

\section{Implementation of wall steepening trials}

In order to implement the $20 \mathrm{~m}$ bench height, the sensitivity of the slope to structural (bedding and joints) condition was tested in RS2 software. The results were presented to management and a trial implementation was accepted to be carried out in Stage 2 pit. The key parts of the trial included:

- Defining the slope behaviour to structural failure and assessing for overall slope stability: from the finite element analysis displacement occurs in the upper slopes in transition material. The maximum shear strain indicated failures through the rock mass by shearing and toppling along bedding. The shearing occurs mainly in weathered slopes and toppling in the west wall. The obtained overall shear strength factor for safety was $>1.45$ with no risk of failure.

- Determining the bench level and consideration of rock or slope domain/sector: creating slopes $\geq 75^{\circ}$ batter angle at $20 \mathrm{~m}$ on both east and west walls, below $15 \mathrm{~m}$ high benches with $75^{\circ}$ batter angle. Incorporating presplit and free faced trim blasts to provide sufficient wall control blasting adjacent to geological structures, weak rocks and berm crest position and provision of a free face for material to move away from the wall and without damaging the wall.

The trialled $75^{\circ}$ batter angles and $20 \mathrm{~m}$ bench slope was applied to all slopes over two benches, whilst the $80^{\circ}$ batter over $20 \mathrm{~m}$ was developed for one bench across the pit. Noting the walls were presplit, significant bedding undercuts and toppling instability were observed in the east and west walls respectively. To remove the undercut and toppling instability, the last two benches were developed using $75^{\circ}$ slope angles. However, for all the $20 \mathrm{~m}$ high benches the walls were configured with $15 \mathrm{~m}$ high presplit plus $5 \mathrm{~m}$ batters and buffer wall controls, the reason being that the site did not have the capacity to drill $20 \mathrm{~m}$ presplit. 


\section{$7 \quad$ Steep slope performance evaluation}

\subsection{Slope stability analysis}

The stability of the slopes was investigated at varying berm size as low as $5 \mathrm{~m}$ wide (assuming berm crest lost damage). As no rock mass strength or material properties were changed, the factor of safety was $>1.35$ which agreed with the St Ives design criteria. The main geotechnical hazard identified was rockfalls, particularly within the $80^{\circ}$ batter bench due to bedding being undercut. From rockfall analysis, a travel distance $>10 \mathrm{~m}$ was identified.

The design batter-berms were compared with the as-built for $15 \mathrm{~m}$ and $20 \mathrm{~m}$ highwalls. An example summary of the berms compliance with design is shown in Table 2 and graphically represented in Figure 7 . The under-compliance was related to the presence of cross sub-horizontal joints at berm crest, which was localised where rock mass appeared blocky to slabby. The berm crest loss in $75^{\circ}$ at $15 \mathrm{~m}$ batters are similar to the $75^{\circ}$ at $20 \mathrm{~m}$ batters and contrast with the $80^{\circ}$.

Table 2 Example of results for berm compliance

\begin{tabular}{llllll}
\hline Location & $\mathbf{R L}$ & $\begin{array}{l}\text { Design width } \\
(\mathbf{m})\end{array}$ & $\begin{array}{l}\text { As-built width } \\
(\mathbf{m})\end{array}$ & $\begin{array}{l}\text { Compliance } \\
(\%)\end{array}$ & $\begin{array}{l}\text { Average } \\
\text { compliance (\%) }\end{array}$ \\
\hline Stage 2 - east wall & 245 & 7 & $2.5-6.8$ & $36-98$ & 70 \\
& 225 & 7 & $1.2-6.7$ & $17-95$ & 66 \\
Stage 3 - east wall & 245 & 7 & $1.0-6.9$ & $12-98$ & 74 \\
& 230 & 7 & $2.0-6.4$ & $27-92$ & 70 \\
\hline
\end{tabular}
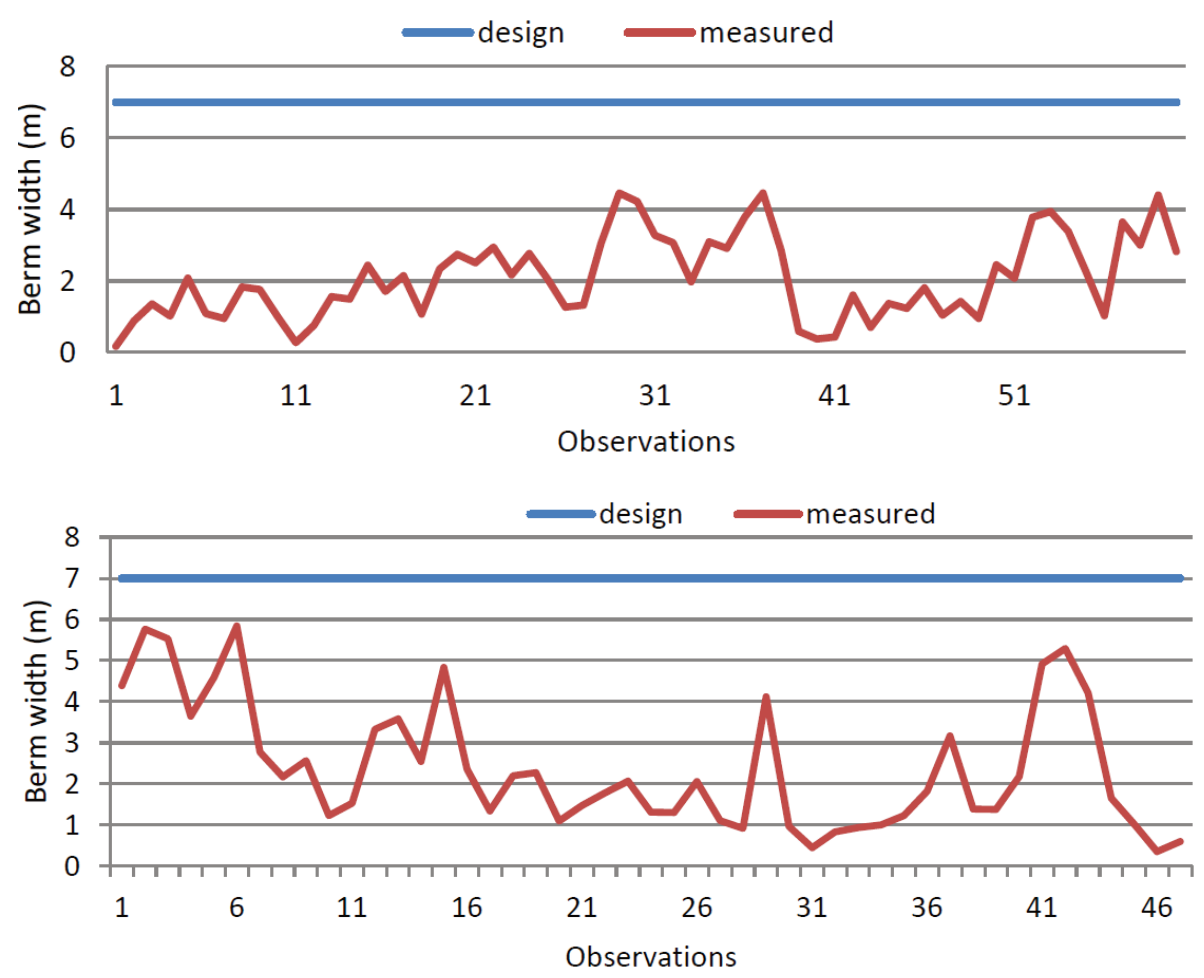

Figure $7245 \mathrm{mRL}$ berm width (top) and $225 \mathrm{mRL}$ berm width (bottom) in Stage 2 pit in fair to good rock mass domain 


\subsection{Key observation from routine mapping and visual inspections}

From the geotechnical mapping, the rock mass was divided into poor to fair and fair to good rock domains. The poor to fair rock domain is defined by walls developed in the BFM with shearing dominating the majority of the formation. The rock mass varies from friable blocky to small blocky. The blockiness is due to intense bedding and shearing. The fair to good rock domain is differentiated by medium blockiness and becoming larger blocky and away from shearing influence. It was observed within the poor to fair rock mass that, the damages in the walls are attributed to interaction of bedding with shear planes and blast overbreak due to interaction of poor rock mass to buffer row designs, and inaccurate drilling resulting from deviation due to fracturing.

To improve the design of buffer rows and for good wall control blasting within the poor to fair rock domain:

- Where weak rock mass and intense shearing occurs, line drilling which involves two to three rows of trim shot with a presplit line, but leaving the presplit uncharged, was utilised to potentially reduce damage to the wall.

- To prevent or minimise breakage beyond the final wall, the above was applied to extremely bedded/foliated and/or sheared rock mass, but with charging the presplit line lightly (toe charging) by using less explosives with greater length of airgap and gas bag for trim blast, and less explosive with greater length of airgap minus gas bag for presplit holes.

- The open holes were drilled using, for example, a $102 \mathrm{~mm}$ diameter drill bit at $1.2 \mathrm{~m}$ spacing and $89 \mathrm{~mm}$ for the charged holes at 0.8-1 m spacing.

- A full free face trim shot is utilised in all the rock domains, with adequate delay of holes towards the split in partially free face trim blasts.

\section{Investigation into drill and blast and wall excavation practices}

As the overall performance of the $20 \mathrm{~m}$ bench heights was embraced by management, and the technical and production team, the performance of the walls within the varying rock domains necessitated the need to carry out a further geotechnical review on drilling, blasting and excavation. The site observed that despite the presence of presplit, some benches have shown berm damages that can obviously be linked to the occurrence of unfavourably oriented rock joints relative to the pit walls and/or large amount of energy directed into the rock mass (even though this is not quantified).

While not all the berm crest damage is immediately visible, in many cases it becomes apparent during wall scaling. To achieve the desired batter conditions, the walls are scaled to hard surface where key rock blocks are removed and in the process the berm crest is damaged and the required catch berm widths to retain rockfall are not being achieved. This is worsened where the rock mass appears blocky and friable.

\subsection{Investigation process}

The team that carried out the investigation and that were facilitated by the site geotechnical engineering team included a drill and blast foreman, supervisors, engineers, the mine superintendent and supervisors, mine geologists, the quarry manager and a business improvement specialist.

The investigation was completed using the root cause analysis toolkit. The toolkit comprised the ' 5 Whys Charts' and the 'Solution Matrix' toolkits. The ' 5 Whys' provided a framework to ensure the relevant facts and information were captured. The ' 5 Whys' was chosen to establish if there is anything the team could have done to have prevented berm damages. In the solution matrix chart, the information and evidence gathered was used to provide a solution to the berm damage. Figure 8 shows an example of the relevant ' 5 Whys' information that was collected for a particular pit area. 


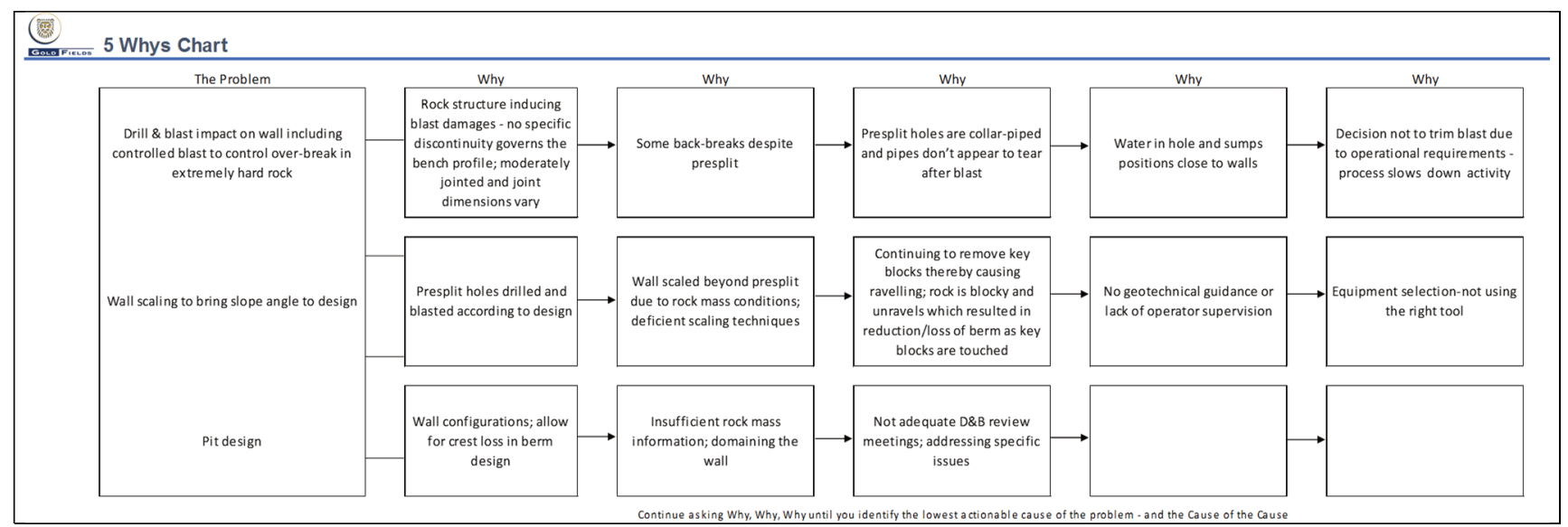

Figure 8 The cause tree analysis used to identify the root cause of the drill and blast and excavation problem

\subsection{Key observations}

While the walls in the pit are controlled using presplit, the primary cause of berm crest damage was found to be:

- Rock structure: occurrence of unfavourably oriented rock joints relative to the pit walls; the rock mass has contributed to the presplit to partially break toward the wall side causing blast overbreak.

- Insufficient horizontal breakage between presplit holes: presplit holes are supported using collar pipes and there is apparently little or no visible breakages of collar pipes after a blast.

- Mismatching between explosive types and rock types and/or large amount of energy adjacent to the batter/directed into the rock mass (even though this is not quantified).

- Scaling of the walls beyond presplit line and continuous removal of key rock blocks.

Additionally, the lack of geotechnical guidance or lack of excavator operator supervision, and insufficient rock mass information (domaining the wall), was identified as contributing to berm crest loss. It was also identified that the walls are not battered using the right equipment. During the investigations, it was proposed to introduce free faced trim blasts, verify field implementation, and excavate the wall/berm to grade.

\subsection{Root causes}

The root cause of crest damage (Figure 9) was attributed to drill and blast design and lack of excavator operator supervision. In order to achieve success and the improvement of wall control and reduction of berm crest damage:

- It was critical for geotechnical engineer(s) to engage with drill and blast engineers/foreman to review blast parameters. Geotechnical engineer(s) provided update on rock mass condition of the wall to the drill and blast team through wall mapping in order to select the right blast parameters.

- Consideration of weekly drill and blast review meeting to share knowledge, learn and innovate and open to change. This meeting was initiated and held every week to critically evaluate the wall control drilling and blasting results, and all identified areas of concerns were highlighted and changes to design were made.

- Any wall that was deemed 'geotechnical proven poor ground condition' by the geotechnical engineer(s) required the work instruction before wall is scaled. The work instructions were signed off by the surface mining manager/quarry manager and as a requirement the geotechnical engineer(s) provided physical inspection/guidance to excavator operator(s) and/or pit supervisor. 
The inspection by geotechnical engineers intended to critically assess key rock blocks or rock structures that could cause wall damage to be well delineated and identified the limits to which the excavator operator could dig.

- The excavator operators were educated to have adequate understanding of key rock blocks in the slope face.

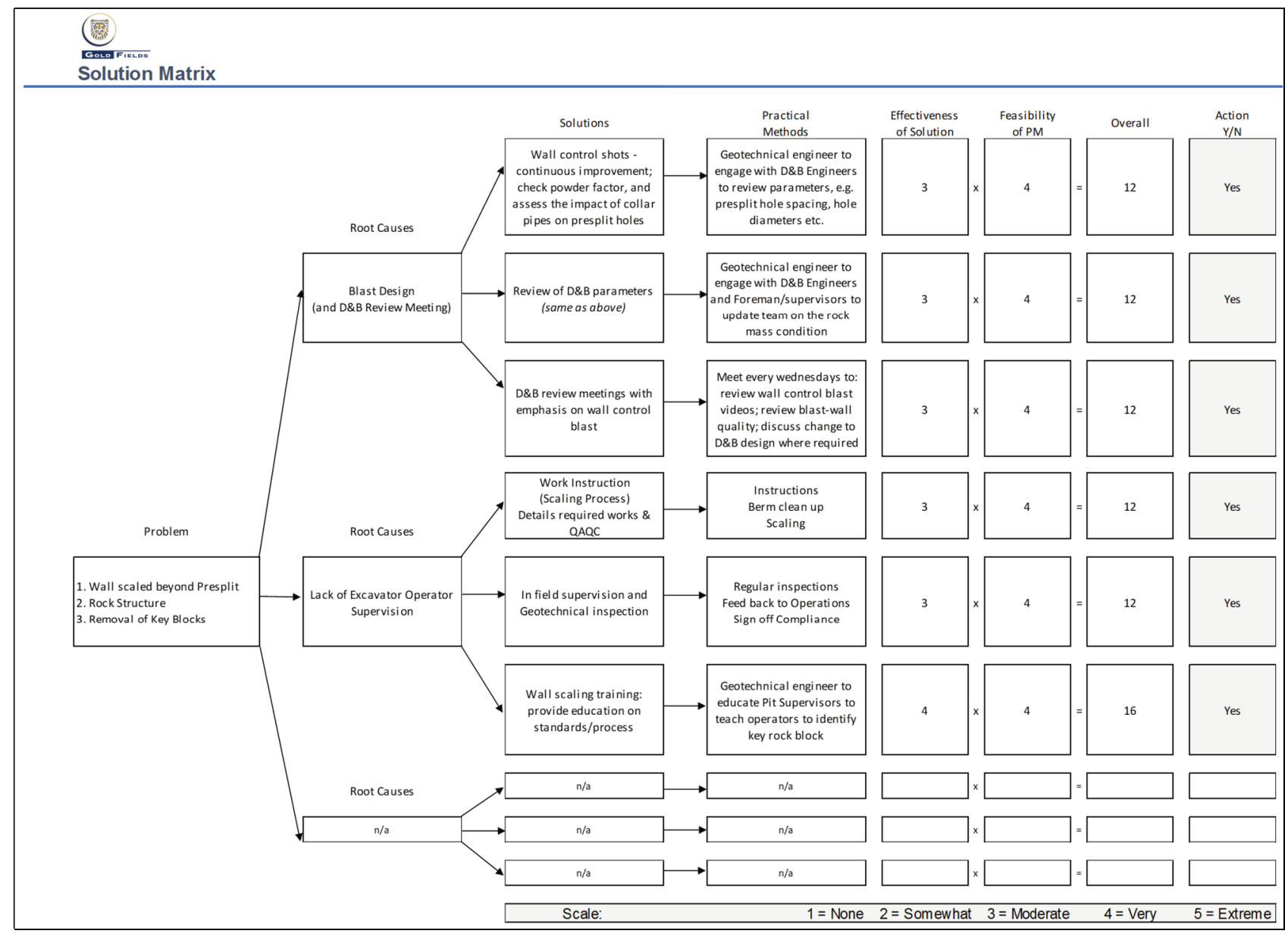

Figure 9 Summary of root causes

\section{Improvement in drilling, blasting and excavation management}

To achieve the designed wall shape and functions, improvement to the following practices were considered adequate:

- Floor control - significant control to dig to the floor design level especially ofr the berm crests. It was observed during stage mining that mining floors in transitional materials and the first bench in fresh rock material were $>0.5 \mathrm{~m}$ above the design level and the berms were attempted to be formed above the designed level. This was seen as poor practice and needed to be modified as soon as practical. This scenario is explained in further detail.

- Reintroduction of negative sub-drill over all berms and crests to assist the formation of stable crests and berms. This scenario is explained in further detail.

- Where the geology shows close fractures or joints running into the walls, full free facing the trim shot was standardised, and the trim shot width of no greater than $1.5 \times$ bench height was used. This approached greatly enhanced the last row of holes from moving away from the wall without detrimental back-break. This scenario is explained in further detail. 
- Reduction of ammonium nitrate content of the bulk explosives in the buffer and batter rows of blastholes (closest two rows to the wall). A 70/30 formulation is seen as excellent for production mining but not helpful when significant geological fractures/structure and bedding planes are present in the walls. As a result, 70/30 was removed from the walls and replaced with 90/10 (or 80/20) formulation for wall control. This scenario is explained in further detail.

\subsection{Floor control - the diagrams and photos in this scenario present examples only and are not specific to the Invincible pit}

Figure 10 shows an example of a blast that was supposed to form the design berm and the crest at $195 \mathrm{mRL}$. It can clearly be seen that the mining had not excavated down to the $195 \mathrm{mRL}$ and all presplit, buffer and batter rows were collared for approximately $1.3 \mathrm{~m}$ above their design. This implies that all explosive energy distribution is also now closer to the 'design' crest and berm than planned.

It also indicates that when an excavator operator tries to form the $195 \mathrm{mRL}$ berm crest, the operator would need to dig the $195 \mathrm{mRL}$ berm down $1.3 \mathrm{~m}$ to arrive at this point, about $5 \mathrm{~m}$ off the wall. Just how the excavator operator judges this accurately is not known. In this situation a $5 \mathrm{~m}$ bench is in fact $6.3 \mathrm{~m}$ (i.e. the $5 \mathrm{~m}$ bench height plus $1.3 \mathrm{~m}$ not dug), this results in $20 \%$ more drilling across the entire pattern than is required.
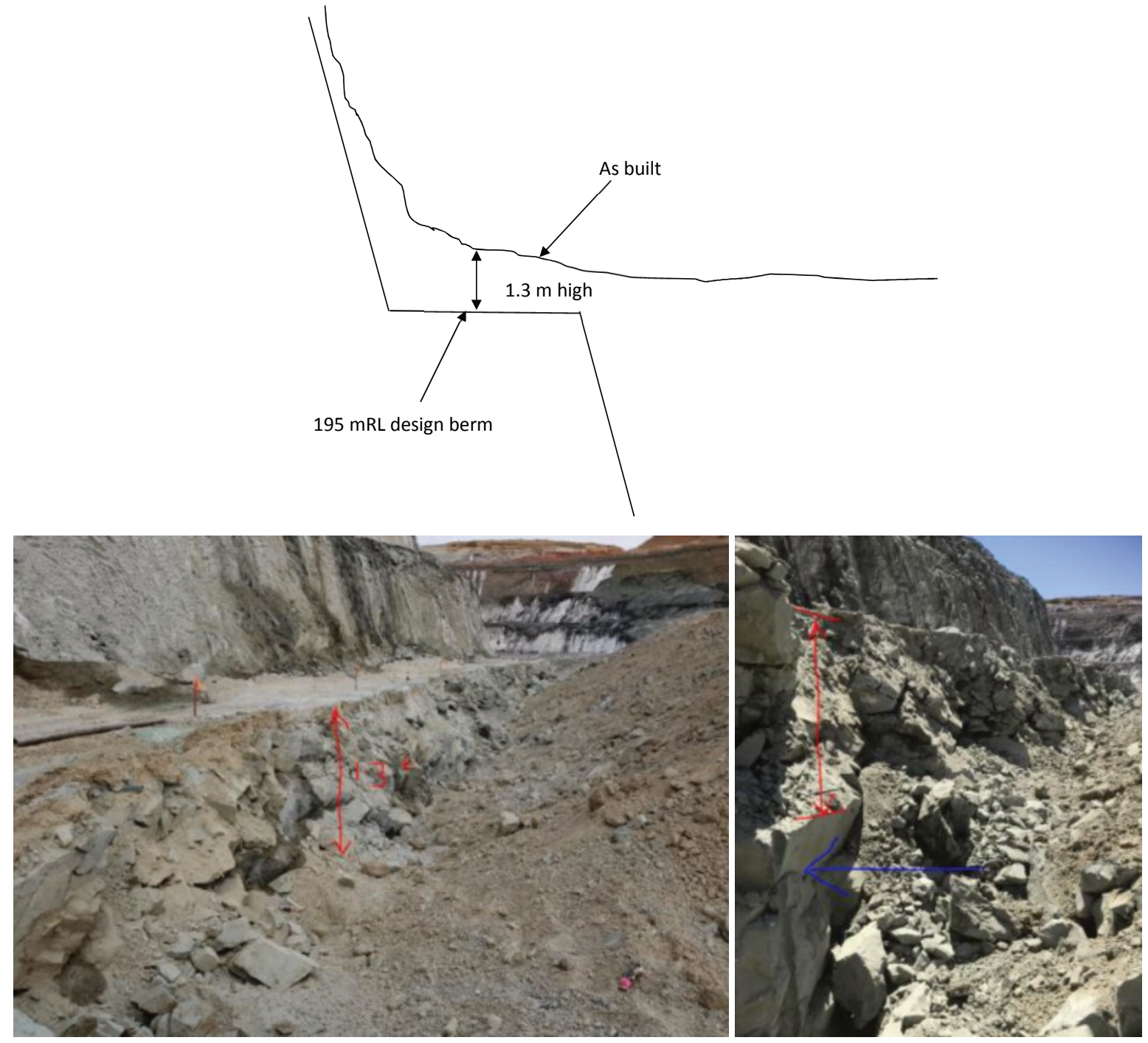

Figure 10 Sketch showing example of blast with floor control issue (top); Photographs showing blast floor control issue (McMahon 2019) (bottom) 
For example, looking at the photograph in Figure 10, there is considerable broken ground that is visible as shown in the red arrows. This is the bottom of the previous blast from above and not damage from the actual blast that is intended to form the crest and berm. The photograph on the right, shows clearly that the blue arrow is pointing to a drillhole barrel, which is the last row of holes in the blast that was loaded with $2 \mathrm{~m}$ explosives, $2 \mathrm{~m}$ airgap, and $2 \mathrm{~m}$ of stemming. Significantly one can see that the barrel indicates minimal damage behind that blasthole, but above it the wall is crushed and heavily broken. This is the area above the blasthole which was not dug down to grade as shown by the red arrow.

\subsection{Introducing negative sub-drill over all berms and crests}

Since geology and rock mass discontinuities play significant role in the structural integrity of the rock, there is the need for careful use of explosives to reduce their influence on the geology. In the heavily fractured and altered ground the zero sub-drill allows a damage circle below the blasthole. The two design sections shown in Figure 11 demonstrate this.
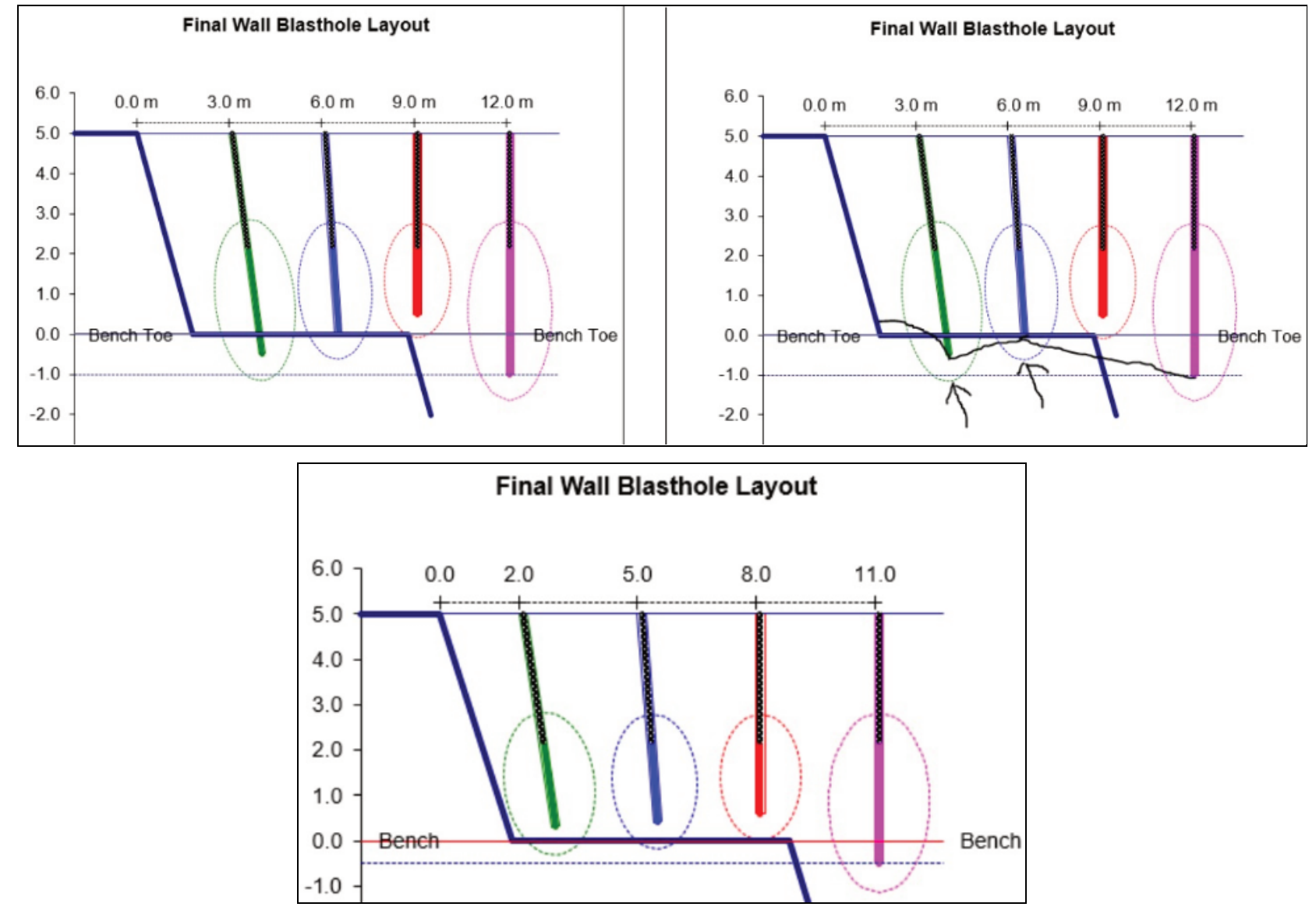

Figure 11 Zero sub-drill showing damage circles below blastholes (top), negative sub-drill showing damage circles below blastholes (McMahon 2019) (bottom)

The berm and crest must be free of all damage circles and the break-out angles from those blastholes. As the black arrows in the top right image in Figure 11 indicates, the 'pink' deep sub-drill and the 'blue' and 'green' damage circles create a failure plane which weakens the berm and crest, such that as the rock strength decreases (along with the increase in fracture frequency) then the potential for diggers to pull these blocks apart increases. The section below shows the negative sub-drill and the damage circles created.

It is important to note in Figure 11 (bottom) that the 'pink' production row also has reduced sub drill because it creases a break-out angle towards which the 'red', 'blue' and 'green' will fracture. The key here is that the crest should not be intersected by that line. Often a toe or solid footing on a berm or crest is seen as failure 
by drill and blast to blast perfectly, however a rough solid berm and crest which achieves the design catchment capacity, may be far more desirable than a tidy cleaned slope which has no catch capacity.

\subsection{Trim width and free facing}

Again, when the geology and rock strength are dominated by fracture frequency and/or structural orientation, the most effective way to reduce damage to the final wall is to fully free face the trim blast. However, there is a common misconception about the free face affect. The depth of the trim is critical, as the final holes next to the wall must be able to move forward towards the void/free face, to reduce the net effect on the wall. This is achieved only if the width of the trim blast does not exceed $1.5 \times$ bench height. In the case of Invincible pit, $10 \mathrm{~m}$ bench height requires $15 \mathrm{~m}$ trim width as maximum width to allow the wall to be 'relieved' at the time of the closest hole blasting to it. Figure 12(a) shows that a full free face is not occurring with the trim blast.

The blasted material obscures or crowed the crest and berm such that it is very unclear where the crest is or is meant to be (Figure 12(a)). Relief can be seen, when the muck pile from a trim blast never exceeds the bench height and one will see a rill of rock slowly decreasing away from the wall. This indicates that the rock movement was forward and not up, as it is the upward movement which strongly drives the damage at the wall interface. Figure 12(b) attempts to demonstrate the movement away and down to avoid back-break; this was a $20 \mathrm{~m}$ bench height and $30 \mathrm{~m}$ trim width.

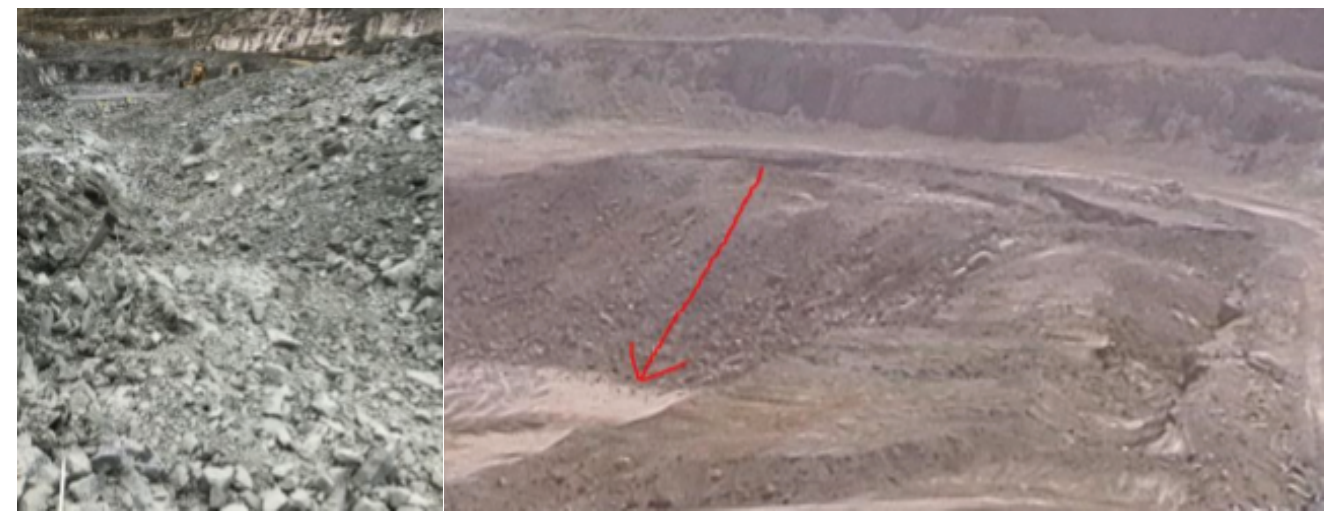

(a)

(b)

Figure 12 Trim width and free face blast (McMahon 2019): (a) Rocks crowded at crest; (b) Rock movement forward and not up

\subsection{Removing 70/30 ammonium nitrate formulation in the last two rows of holes against the wall}

In most Gold Fields mine sites, the $70 / 30$ product is utilised to enhance the dig-ability of the production blast. This is because the $30 \%$ ammonium nitrate addition to the emulsion is a great assistance to loosening the much pile to increase dig rates of excavators. It is the ammonium nitrate component that produces the 'effect' of gas distribution into the muck pile. In many instances it became obvious that using 70/30 product has a detrimental effect upon the heavily fractured rock that is randomly encountered. For example, Figure 13 shows the rock in a wall, when 70/30 was used in the last two rows of holes next to the walls.

Figures 13(a) and 13(b) show presplit holes which have been dislocated by the movement of the blocks. This movement occurs when the explosive gases are trapped in the bedding planes and wedge them apart. The key to reducing this is to either reduce the amount of gas or increase the amount of relief the gas can find to escape out the presplit holes. This can be achieved by reducing the $30 \%$ ammonium, or by closing the presplit spacing to say $1.0 \mathrm{~m}$ and only blasting every second hole. This allows the non-charge hole to act as a cracking plane and gas relief passage. Figure 13(c) shows a large block opened at its bedding plane by the gas from the explosive within the blast. To limit this, the site took the decision to reduce the $30 \%$ ammonium to $10 \%$ or even zero. 

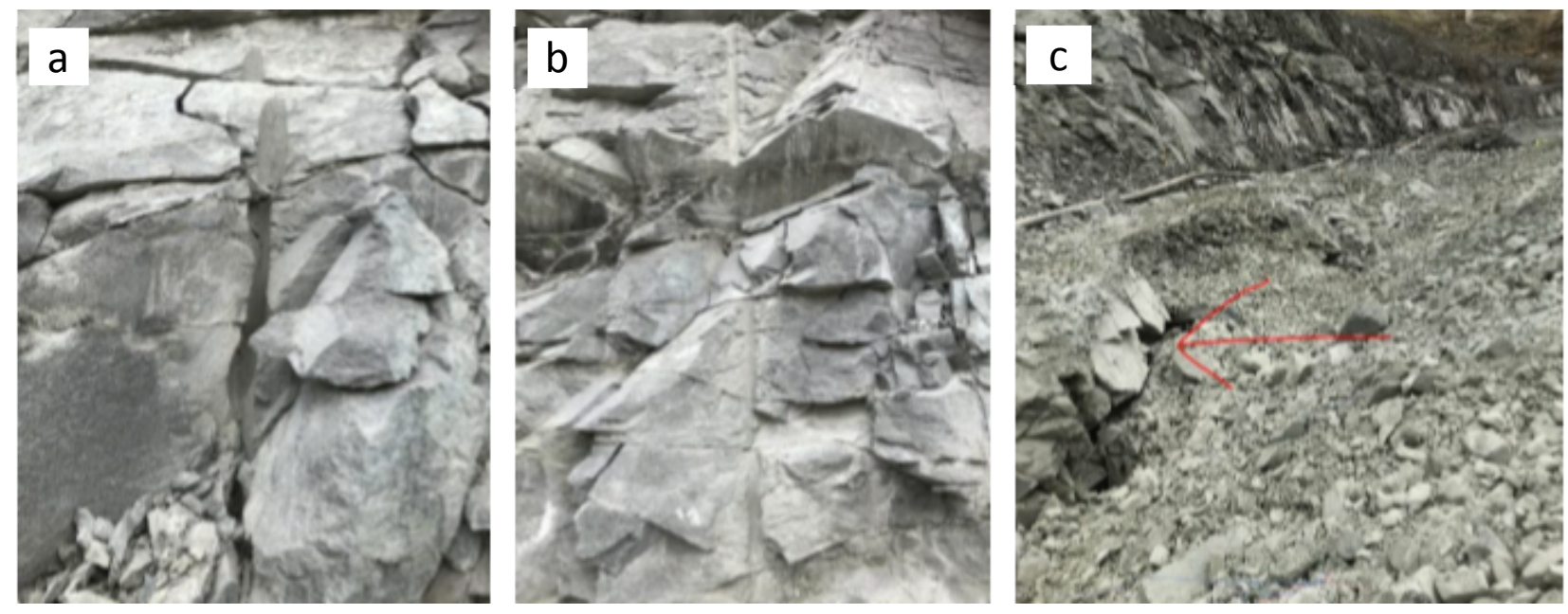

Figure 13 Wall damages resulting from 70/30 ammonium nitrate formulation. ( $a$ and $b$ ) An example of presplit holes dislocated by of blocks $(a, b)$; (c) Large block opened at bedding plane by gas from explosive within explosive (McMahon 2019)

\section{Conclusion}

The St Ives Gold Mine has utilised opportunities presented in the stage pits to investigate the likely performance of the final walls in Invincible pit and to trial and develop improvement in its drill and blasting and excavation processes. This was done through geotechnical analysis and incidence investigation methodology. The history of past slope performance is part of the pit slope design process at St Ives Gold Mine and use as improvement tool for our design process. The implementation of greater batter height at Invincible pit has been successful and overall, the pit walls have adequately performed to geotechnical requirements.

The drill and blast design, and final wall scaling is a process that is not to be complicated, but to recognise when something is not working. To achieve the desired results, there must be the need to change a process; through continual refinement of the techniques the amount of crest damage may be reduced to acceptable level.

\section{Acknowledgement}

The authors acknowledge Gold Fields Australia - St Ives Gold Mine for permission to publish this paper, the open pit management team for allowing this work to progress, and the group technical team for support throughout the project. Many thanks to the drill and blast and mine production team for their collaboration during the trials.

\section{References}

Bruggeman, D 2014, Geotechnical Report - Invincible Open Pit Project, internal report.

Itasca Pty Ltd 2014, Two-dimensional Numerical Analyses for Invincible Open Pit, Internal Report, Ref. No: 14012_1, Melbourne. McMahon, D 2019, SIGM - Site Visit Report Neptune and Invincible Stage 6 Pits, internal memo.

Walker, D \& De Bruyn, I 2006, 'Geotechnical blockiness index: a systematic geotechnical mapping method for underground and open pit mines', in B Harris, W Potter \& B Scott (eds), Proceedings of the 7th Australia - New Zealand Young Geotechnical Professionals Conference, Australian Geomechanics Society, Sydney. 